\title{
Tilgivelsens teologi i Det Gamle Testamente
}

\author{
Cand.theol., ph.d. \\ Carl Lombolt
}

\begin{abstract}
This paper studies the Old Testament's conception of forgiveness, which is characterized by its one-sidedness. According to the almost unambiguous testimony of the OT literature, only God can forgive. However, it is important to see God's unreserved forgiveness against the background of his resentment at the apostasy and sin of man. At the same time the OT also weights God's punishment and grace in favour of his grace. The paper also discusses the few OT examples of human forgiveness, noting them as remarkable exceptions which confirm the main thesis of the one-dimensional aspect of forgiveness. This aspect is due to the fact that the OT does not know the incarnation of God. It is not until the New Testament that there is a necessary connection between God's forgiveness and the willingness of man to forgive his neighbour.
\end{abstract}

Key-words: Genesis - Exodus - forgiveness - blessing - apostasy - sin - resentment - grace

\section{Indledning}

Denne undersøgelse handler om tilgivelsen, som den udtrykkes i Den hebraiske Bibel, Biblia Hebraica (BH). ${ }^{1}$ Fokus retter sig mod, hvad tilgivelsen siger om Gud, som baggrund for en udfoldelse af tilgivelsens teologi i Gammel Testamente. Undervejs vil $\mathrm{BH}$ oftest blive betegnet som Gammel Testamente (GT), selv om disse to skriftsamlinger ikke er ganske identiske. ${ }^{2}$

1. Den her anvendte udgave er Biblia Hebraica Stuttgartensia, red. A. Schenker (Stuttgart: Deutsche Bibelgesellschaft 1997).

2. Forskellen mellem BH og GT består, foruden mange sproglige nuancer, især i den meget forskellige rækkefølge og dermed prioritering, hvorefter de enkelte skrifter er anbragt i de to samlinger. Indholdet har de dog fælles. Når skriftstedshenvisninger i afhandlingen forekommer i rækkefølge, er de ordnet efter de respektive skrifters rækkefølge i BH. 
Modsat den almindeligt udbredte forestilling om, at den Gud, ${ }^{3}$ som vi møder i GT, frem for alt må karakteriseres som vred og dømmende, vil den foreliggende tekst argumentere for GTs væsentligste budskab som dette, at "Jhwh er en barmhjertig og nådig Gud, sen til vrede og rig på kærlighed og troskab" (2 Mos 34,6b). ${ }^{4}$

Under det synspunkt, at samtlige skrifter i GT og Ny Testamente (NT) er overleveret som kirkens kanon, er afhandlingen et bidrag til bibelsk teologi på kanonisk grundlag. Den metodiske tilgang til emnet har en dobbelt perspektivering:

1) Undersøgelsen tager udgangspunkt i det bekendelseslignende udsagn, 2 Mos 34,6b-7, som et genuint udtryk for gammeltestamentlig gudsopfattelse.

2) I nøje sammenhæng hermed gøres der rede for tilgivelsens udpræget endimensionale karakter i GT, hvor det med få undtagelser gælder, at kun Gud kan tilgive, til forskel fra NT, hvor tilgivelsen er todimensional, idet Guds tilgivelse til mennesket og menneskets tilgivelse til dets næste hænger uløseligt sammen.

Det gammeltestamentlige materiale behandles på dets egne præmisser. Kun på den baggrund kan det ses $\mathrm{i}$ et dialektisk forhold til NT, jf. B. S. Childs' kanonforståelse: "The Christian canon maintains the integrity of the Old Testament in its own right as scripture of the church. However, it sets it within a new canonical context in a dialectical relation with the New Testament." 5

Udover de øvrige forskere, som citeres, henvises der særligt til Hermann Spieckermann og Erik Aurelius.

H. Spieckermann, professor i GT, og R. Feldmeier, professor i NT, har i fællesskab udgivet en bibelsk teologi, hvormed de, som det hedder i forordet, vil præsentere "das Gotteswissen der christlichen Bibel als einen kohärenten Entwurf". ${ }^{6}$ I et bibelsk tværsnit behandler de emner som eksempelvis retfærdighed og tilgivelse, således at henholdsvis den gammeltestamentlige og nytestamentlige behandling af stoffet inden for hvert større afsnit fremstår selvstændigt i hver sit underafsnit. I det fælles projekt, om hvilket man passende kan bruge Childs' standardudtryk, "canonical approach", lægger de to forfattere

3. Bortset fra citater, hvor navnet Jhwh forekommer, bruges gennemgående betegnelsen Gud.

4. De bibelske citater i artiklen er oversat af dens forfatter i den hensigt at komme den hebraiske tekst nærmest muligt.

5. Brevard S. Childs, Old Testament Theology in a Canonical Context (London: SCM Press Ltd 1985), 9. Bogen er et af de seneste forarbejder til Childs' samlede bibelske teologi, Biblical Theology of the Old and New Testament. Theological Reflexion on the Christian Bible, London 1992.

6. Reinhard Feldmeier, Hermann Spieckermann, Der Gott der Lebendigen. Eine biblische Gotteslehre (Tübingen: Mohr Siebeck 2011), VII. 
ikke fortløbende navn til underafsnittene; men da disse holdes klart adskilt, er det ikke svært for læseren at se, hvem der har skrevet hvad. Med dette forbehold citeres Spieckermann i det følgende for værkets gammeltestamentlige udredninger.

Aurelius har som et centralt anliggende i sin disputats om Mosesbilledet i GT gennemgået kapitlerne, 2 Mos 32-34, som er særlig vigtige for nærværende undersøgelse. I modsætning til et statisk begreb om den gammeltestamentlige Gud som den evigt uforanderlige argumenterer Aurelius overbevisende for tesen om Guds foranderlighed. Den straffende Gud bliver ved nådens mellemkomst den tilgivende Gud. $^{7}$

Offer og soning. Og tilgivelse ubetinget af kult

I store dele af GT, navnlig tekster præget af eftereksilsk, præstelig teologi (P), er soningen / tilgivelsen især knyttet til offerkulten. I den omfattende kultiske lovgivning, særlig i 3. Mosebog, er den sonende virkning af offeret selve omdrejningspunktet i tempelkulten. Nøgleordet er pi'el- formen כפר "sone". I den sammenhæng spiller "syndoffer" og "skyldoffer" en vigtig rolle. I føreksilsk tid præges billedet snarere af offeret som gave eller tak i form af førstegrødeoffer, brændoffer og slagtoffer. Ofringerne samt de dertil hørende måltider fandt typisk sted ved offerhøje og andre lokalhelligdomme, jf. festkalenderne 2 Mos 23,14-19; 34,18-26, endv. 1 Sam 9,12ff; 1 Kong 3,4; 2 Kong 12,4; Hos 10,8; Am 7,9; Mika 1,5. Men allerede i de to festkalendere, hvoraf i hvert fald den første (fra Pagtsbogen) er føreksilsk, mærkes bestræbelserne på at samle kulten i Jerusalem, jf. 2 Mos 23,17 og især 34,23.24c. Den endelige centralisering forudsætter den udvikling, der markeres med kong Josijas reform 622 f.Kr. De mange offertyper præsenteres i 3 Mos 1-7. Men der er gode grunde til den formodning, at offerkulten som sådan har markeret sig over tid både ved stabilitet og kontinuitet.

Styrken i soningsteologien er, at den tager skylden alvorligt som skyld til døden. I offerritualet tager Guds ja til livet skikkelse i og med soningen. Mennesker udfører offerhandlingen, men i soningen er Gud subjekt. Offeret er i GT forstået som den af Gud selv forordnede kult, der kan øve indflydelse på hans handlinger, dog, som

7. Erik Aurelius, Der Fürbitter Israels. Eine Studie zum Mosebild im Alten Testament, CB 27 (Stockholm: Almqvist \& Wicksell International 1988), 57-126. 
Spieckermann understreger, "unter Wahrung der Souveränität und Unverfügbarkeit des göttlichen Willens" (Feldmeier 2011, 313).

Trods offerkultens position i Israel, forekommer langt de fleste udsagn om tilgivelsen dog uden forbindelse med offer og helligsted / tempel. Vi må med Spieckermann antage, at denne ikke-kultiske opfattelse af tilgivelsen frem for alt har vundet frem i diasporajødedommen, (Feldmeier 2011, 316). Og da det meste af den deuteronomiskdeuteronomistiske litteratur er blevet til omkring og navnlig efter eksilet, er det den ikke-ritualiserede tilgivelse, der har størst udbredelse i GT. Det er især denne opfattelse af tilgivelsen, som er genstand for undersøgelsen.

\section{Fortællingen om den nådige Gud}

Hvad vi kalder "urhistorien" (1 Mos 1-11) er verdens begyndelse set i jødiske skriftlærdes perspektiv i 6.-5. årh. f.Kr. I det samme perspektiv er patriarkhistorien, fortællingerne om Moses, ørkenvandringen, indvandringen og Landnahme blevet til. Vi skal helt frem til kongetiden, altså efter år 1000 f.Kr., før vi i moderne betydning er på blot nogenlunde fast historisk grund. Med disse bemærkninger in mente kan vi tage udgangspunkt i "begyndelsen".

Guds historie med verden begynder med skabelsen, blevet til på hans ord (1 Mos 1,3-30; Sl 33,9; 148,5 m.fl.) eller udført som hans gerning (1 Mos 2,7-22; Sl 74,13-17; 89,9-14; 104; Job 26,7-14; 38-39 m.fl.). Alt, hvad Gud havde skabt, var godt. Og da menneskene havde vendt sig bort fra Gud og fordærvet livet for sig selv og hinanden samt alle andre skabninger, og den store vandflod havde skyllet altødelæggende hen over jorden og kun skånet en rest, nemlig Noa og hans nærmeste, samt de dyr, som var nødvendige for arternes fortsatte eksistens, så begyndte Gud forfra med tilgivelsen ved den nye skabelse (1 Mos 6-8). Tilgivelsen var ikke begrundet i Noas fromhed eller hans offer, men alene i Guds godhed på trods af menneskenes uudryddelige ondskab $(8,20 \mathrm{f})$. Derfor velsignede Gud Noa og hans sønner og dermed hele menneskeslægten. Velsignelse og forjættelse til en syndig slægt er tilgivelse. Denne universelle tilgivelse beseglede Gud ved at oprette pagten med Noa og hans slægt med tilsagnet: "Aldrig mere skal alt levende udryddes af vandfloden." Og som pagtstegn satte Gud regnbuen i skyerne (9,1.9-17).

Og Guds historie med hans folk begynder med forjættelsen til Abraham; men også den er universel, som det siges til Abraham og patriarkerne efter ham: "I dig skal alle jordens slægter velsignes." (1 
Mos $12,3 b ; 18,18 ; 22,18 ; 26,4 ; 28,14)$. I en helt anden genre af den gammeltestamentlige fortælling kommer Sinajperikopen med lovgivningen (2 Mos 19f), som forudsætter Guds befrielse af sit folk fra trældom $(20,2)$, og som ikke sætter forjættelserne ud af kraft, men tværtimod stadfæster dem $(19,5 ; 20,6)$.

Kort sagt, GT handler i første række om nåden. GT drejer sig ikke om lov og evangelium, men om evangelium og lov. Derfor kan Spieckermann sige om GT.s Gud: "Die Vergebung ist ihm opus proprium, das Gericht opus alienum" (Feldmeier 2011, 317). Guds barmhjertighed er udgangspunktet i hans forhold til den forkvaklede menneskeslægt, og barmhjertigheden sættes i relief af enhver tale om vrede og straf, hvilket tydeligt fremgår af credoet, 2 Mos 34,6b -7:

Jhwh, Jhwh er en barmhjertig og nådig Gud, sen til vrede og rig på kærlighed $^{8}$ og sandhed. Han bevarer (sin) kærlighed i tusind slægtled, tilgiver skyld og overtrædelse og synd. Men han lader ikke den skyldige ustraffet, han hjemsøger fædres skyld på børn og børnebørn indtil tredje og fjerde slægtled.

Begrundelsen for at tage afsæt i dette citat er dets centrale placering i toraen. Det står som højdepunktet i afsnittet 2 Mos 32-34, der bedst forstås som opfølgningen af kap. 19-24, blot afbrudt af et langt afsnit af P, kap. 25-31. Ved selve åbenbaringsstedet Sinaj forråder israelitterne Gud med dansen om guldkalven $(32,4-6)$, hvorved de pådrager sig hans tilintetgørende vrede (32,10.12b.34b; 33,3b.5). Trods Moses' indtrængende forbønner fastholder Gud sin vrede, indtil han endelig åbenbarer sig for Moses som den barmhjertige og tilgivende Gud efter først at have givet ham befaling om de nye lovtavler i stedet for de forrige, som Moses havde knust i vrede over folkets forræderi $(34,1-7)$. Med de nye tavler følger den fornyede pagt $(34,10.27)$ som Guds besegling af sit udsagn, 34,6b-7. Det er vigtigt at have folkets oprørende frafald og mellemspillet med Guds vrede in mente, når vi hører 34,6b-7. Ellers mangler vi forudsætningen for denne "nådeformel”. Den Gud, der taler her, har så rigelig grund til vreden, men han er "sen" til den og gemmer ikke for evigt på den. Sagt med

\footnotetext{
8. Spieckermann påpeger i sin semantiske undersøgelse af begrebet $70 n$, at det vanskeligt lader sig gengive med et enkelt ord, men at de, som kommer nærmest, er karlighed, nåde, godhed. Han konkluderer: "Die in der Revised Standard Version bevorzugte Wiedergabe von hesed durch 'steadfast love' scheint der Sache am nächsten zu kommen” Feldmeier (2011), 132. I tilslutning hertil er חסח i nærværende artikel gennemgående oversat ved karlighed, hvilket også iflg. Gesenius er den primære betydning. Wilhelm Gesenius: Hebräisches und Aramäisches Handwörterbuch über das Alte Testament (Berlin / Göttingen / Heidelberg: Springer-Verlag 1962), 247.
} 
Spieckermann er det ikke den vrede, forbitrede Gud, der præger GT, men den Gud, der, selv om han bliver bedraget i sin kærlighed, dog forbliver den elskende uden svig. Dette er den teologiske substans i nådeformlen (jf. Feldmeier 2011, 134). Bonhoeffer har i et af sine breve fra fængslet udtrykt de samme tanker om vreden og nåden: “...nur wenn der Zorn und die Rache Gottes über seine Feinde als gültige Wirklichkeiten stehen bleiben, kann von Vergebung und von Feindesliebe etwas unser Herz berühren."

\section{Straffen på den korte ban, og nåden på den lange}

2 Mos 34,6b-7 har karakter af et israelitisk credo, "the creedal statement". ${ }^{10}$ Dette bekræftes både af udsagnets centrale placering og dets virkningshistorie i de mange sammenhænge, hvori det citeres og afspejles, således 2 Mos 20,5b-6; 4 Mos 14,18; 5 Mos 5,9b-10; 7,9b-10; Es 55,7f; Joel 2,13b; Am 7,1-6; Jon 4,2; Mika 7,18-19; Sl 30,6; 78,38; 86,5.15; 103,8; 145,8; Neh 9,17b. ${ }^{11}$ Spieckermann taler på samme grundlag om udsagnets autoritative betydning: "Wie die inneralttestamentliche Wirkungsgeschichte zeigt, geniesst die überlegte Annäherung an Gottes liebevolles Wesen in Ex 34,6f. geradezu autoritative Geltung" (Feldmeier 2011, 133). ${ }^{12}$ Udformet $\mathrm{i}$ et stærkt, poetisk sprog stilles barmhjertigheden og straffen side om side, vel at mærke sådan at tilsagnet om barmhjertigheden kun forstærkes af ordene om straffen. Mellem nåden og vreden er der, som Konkel udtrykker det, "eine 'Asymmetrie' zurgunsten der Gnade"..$^{13}$ Overordnet og i modsætning til den tidsbegrænsede straf indtil tredje og

9. Dietrich Bonhoeffer, Widerstand und Ergebung. Briefe und Aufzeichnungen aus der Haft, udg. E. Bethge (München: Kaiser 1955), 113.

10. Jf. John S. Kselman, "Forgiveness. Old Testament", The Anchor Bible Dictionary, ABD, (New York: Doubleday 1992), 831.

11. Dertil kommer lang række steder, hvor der formodentlig hentydes til dette credo: 2 Mos 33,19; 5 Mos 4,31; Es 48,9; 54,7f; 63,7; Jer 3,12; 15,15; 32,18; Sl 99,8; 111,4; 112,4; 116,5; Dan 9,4; Neh 1,5; 9,31b; 2 Krøn 30,9; Sir 2,11; 5,4-7. Jf.

Feldmeier (2011), 136.

12. Som eksempel nævnes den formentlig sent eftereksilske $S 186$, hvor der med v. 5 er ansats til en nytolkning af nådeformlen (2 Mos 34,6b-7), udformet som bøn, hvorefter formlen i salmens v. 15 citeres som traditum med autoritativ gyldighed, jf. Feldmeier (2011), 138.

13. Jf. Michael Konkel, Sünde und Vergebung. Eine Rekonstruktion der Redaktionsgeschichte der hinteren Sinaiperikope (Exodus 32-34) vor dem Hintergrund aktueller Pentateuchmodelle (Tübingen: Mohr Siebeck 2008), 94. 
fjerde slægtled, står den uendelige barmhjertighed, ${ }^{14}$ hvormed Gud tilgiver skyld, overtrædelse og synd i tusind slægtled, dvs. for evigt. Et slægtled eller en generation er ca. 30 år. Tusind slægtled er derimod et spand af år, som mennesker slet ikke kan forholde sig til, det eliminerer begrebet tid og er i GT et udtryk for evigheden. Og når Guds kærlighed varer evigt, må den også omfatte de tidsbegrænsede fire slægtled. Det er betegnende, at de få steder, hvor det nævnte credo findes i den fulde ordlyd, kun forekommer i Pentateuken (2 Mos 20,5b-6; 34,6b-7; 4 Mos 14,18; 5 Mos 5,9b-10; 7,9b-10). Det andet af disse fem skriftsteder (2 Mos 34,6b-7) er primært i forhold til de fire andre, som er afhængige af det. 4 Mos 14,18 anføres udtrykkeligt (jf. v. 17) som citat, rimeligvis af 2 Mos 34,6b-7, der således må anses som nådeformlens primærtekst. Dog har Dohmen sikkert ret $\mathrm{i}$, at den teologiske og litterære oprindelse til tanken om uligevægten mellem den guddommelige barmhjertighed og straf (til barmhjertighedens fordel) må søges hos profeten Hoseas, jf. Hos 11,8-9. ${ }^{15}$

I den lange række af skriftsteder, der ovenfor er anført som dokumentation for nådeformlens virkningshistorie, er formlens sidste del (om straffen) bemærkelsesværdigt undertrykt eller fraværende de tolv steder uden for Pentateuken. Dermed gælder det altså både i credoets fulde ordlyd i Pentateuken og i de mange citater af det uden for denne, at den tidsbegrænsede straf så at sige bliver skjult af Guds evige kærlighed. I den forbindelse er det vigtigt at være opmærksom på Deuteronomiums og den deuteronomistiske litteraturs opgør med tanken om, at fædres skyld straffes på de følgende slægtled. Denne forestilling modsiges direkte af 5 Mos 7,10; 24,16; jf. 2 Kong 14,6 med tydelig reference til sidstnævnte sted "i Moses lovbog". ${ }^{16}$ Samme deuteronomiske norm gøres gældende i Jer 31,29f og Ez 18,1-4.

Isoleret vil den afsluttende sætning i 2 Mos 34,6b-7 par., at Gud hjemsøger fædres skyld på de følgende slægtled til og med oldebørnene, stå som en oprørende anfægtelse. Den lader sig ikke fjerne under henvisning til en større sammenhæng, hvor straffen bliver skjult af nåden. Den anfægtede vil i bedste fald opfatte dette som en hjælpeløs apologi for den nådige Gud. Anfægtelsen bliver stående, men bliver først til fortvivlelse, når man isolerer eftersætningen om straffen i ste-

14. Dette forhold ændres ikke ved, at barmhjertigheden og straffen nævnes i omvendt orden både i 2 Mos 20,5-6 og 5 Mos 5,9-10. Begge steder er udsagnet for øvrigt på det nærmeste forbundet med det 1 . bud, hvorved karakteren af et credo fremhæves desto stærkere.

15. Christoph Dohmen, Exodus 19-40. Übersetzt und ausgelegt, HThKAT, red. Erich Zenger (Freiburg/Basel/Wien: Herder 2004), 107.

16. Derfor rammer Guds gengældelse i 5 Mos 7,10 alene den genstridige selv og ikke hans efterkommere. 
det for at lade hovedudsagnet gælde som det egentlige i dette credo: bekendelsen til den nådige Gud, som for evigt bevarer sin kærlighed. Ordene om straffen vil dybest set kun stille denne bekendelse i relief, ligesom den mørke skygge i claireobscur maleriet fremhæver lyset desto stærkere. Især er det vigtigt med Spieckermann at se hele udsagnet under eksilgenerationernes synsvinkel. "Fædrene" er de aktuelle jøders egne forfædre, som de stiller sig solidariske med. Fædrenes skyld er deres skyld. I dette perspektiv er det ikke den begrænsede straf, der er det mærkelige, men derimod den grænseløse kærlighed, hvormed Gud forbliver sig selv og Israel tro (Feldmeier 2011, 134).

Denne vægtning fremhæves med stor poetisk styrke i fire af de ovennævnte citater, som omskriver det nævnte credo, nemlig Sl 30,6; 103,8-9; Es 54,7-8; Jer 3,12.

\section{Guds nærhed i tilgivelsen}

Sideløbende med forestillingen om den ensidigt straffende Gud forekommer tanken om, at Israels Gud i ophøjet majestæt er fjern og fremmed for menneskers verden. Men tværtimod er han netop som den tilgivende Gud helt nær.

Medens gudsopfattelsen i andre antikke kulturer er forbundet med forestillingen om storrigets magtfuldkommenhed, er den i det nok så overskuelige israelitisk-jødiske samfund desto tættere på familien og nærsamfundet; jf. de stærke billeder af Gud som en omsorgsfuld far (fx Sl 103,13) - eller som den inderligt elskende mor (Hos 11,4; Es 49,15; 66,12b-13; Sl 131,2). Gerstenberger bruger udtryk som "Familiengott" og "Familientheologie" og viser, at fortrøstningen til denne nære Gud styrkes under fremmedgørelsen i eksilet. ${ }^{17}$

Dog netop i krisetider, både nationale og personlige, oplevede man ikke alene Guds styrke, men også hans svaghed (således i mange klagesalmer). Guds almagt bliver anfægtet, så han kendes som den afmægtige Gud, hvilket måske er den afgørende teologiske erkendelse i den eksilsk-eftereksilske menighed (Gerstenberger 2001, 182f). Men den afmægtige Guds solidaritet med nedbrudte og syndige mennesker er netop det dybeste udtryk for hans barmhjertighed og tilgivelse.

Således er GT.s Gud allernærmest i sin סליחה "tilgivelse", som også kan kaldes פרות "forløsning". De to udtryk bruges synonymt v. 4 og 7 i Sl 130, "de profundis", der entydigt handler om Guds tilgivelse.

17. Jf. Erhard S. Gerstenberger, Theologien im Alten Testament. Pluralität und Synkretismus alttestamentlichen Gottesglaubens (Stuttgart: Kohlhammer 2001), 26-77. 176-181. 
I sin gennemgang af Sl 130 drager Kirsten Nielsen en tankevækkende sammenligning mellem den og Sl 24. "For hvor Sl 24 forudsætter, at den, der vil ind på helligstedet, har skyldfri hænder og et rent hjerte, dér lægger Sl 130 hele vægten på Guds tilgivelse af den skyldige." I Sl 24 menes mennesket i stand til at opfylde visse betingelser for at kunne nærme sig Gud. I Sl 130 er udgangspunktet derimod, at Gud er aldeles fraværende for den bedende, som råber til ham fra det dybe som fra kaoshavets bund. Her findes ingen menneskelig mulighed for at komme til Gud, for hvis Gud "vogtede på skyld" (v. 3), så kunne intet menneske bestå over for ham. Vendepunktet kommer med v. 4: "Men hos dig er der tilgivelse, for at man skal frygte dig." Guds nærhed er i hans tilgivelse, og gudsfrygten er "ikke en forudsætning for at komme Gud nær, men en konsekvens af den tilgivende Guds nærhed" ${ }^{18}$

\section{Tilgivelse, et begreb med mange udtryk}

Som Guds enehandling er tilgivelsen endimensional; men den formuleres i mangfoldige udtryk, der hver for sig vil sige, hvad tilgivelsen indeholder og betyder. Substantivet o "tilgivelse" forekommer kun Sl 130,4, Dan 9,9 og Neh 9,17b. Med citat af det nævnte credo betegner sidstnævnte sted Gud med navnet אלוה סליחות Tilgivelsers Gud.

Til gengæld findes det tilsvarende verbum oל "tilgive" i alt 50 gange og altid med Gud som subjekt. Bortset fra det føreksilske Am 7,2 forekommer verbet udelukkende i eksilske og senere tekster, jf. (Aurelius 1988, 122).

Ligeså er det alt overvejende Gud, der er subjekt i de mange synonymer for o, jf. (Kselman 1992, 832-833). Enkelte af de i denne sammenhæng særlig ekspressive skal anføres:

Det hyppigst forekommende er verbet נשא, hvor tilgivelsen får betydningen: "bære (synden) bort", dvs. fjerne synden og dens virkninger tillige med straffen. Typisk i sidste linje af Ebed Jhwh-sangen, hvor det om Jhwhs lidende tjener hedder: "han bar de manges synd" (Es 53,12), dvs. han tog den på sig og bar den bort. ${ }^{19}$ Brugt om Gud, der bærer, dvs. tilgiver synden, forekommer נשא mange steder, fx 2 Mos

18. Kirsten Nielsen, "Salme 130", Dansk Kommentar til Davids Salmer. Bind III, red. Else K. Holt \& Kirsten Nielsen (København: Anis 2002), 223-225.

19. Det bemærkes, at det i dette særlige tilfælde er en anden end Jhwh selv, nemlig hans tjener, der tager synden på sig og bærer den bort. Stedet hører for så vidt til de få undtagelser, der bekræfter reglen: at kun Gud selv kan tilgive. 
34,7; Es 33,24; Hos 14,3; Mika 7,18; Sl 32,5; 85,3; 99,8, sidstnævnte sted participialt som gudsnavn: אל נשא Tilgivende Gud.

לא זכר Et andet udtryk for tilgivelsen er vendingen om Gud, der "ikke husker" vore synder. Således i Es 43,25, her sammen med מחר om Gud, der "udsletter" synden, og gør det helt på sine egne præmisser: "Jeg, jeg er den, som udsletter dine overtrædelser for min egen skyld, og dine synder vil jeg ikke huske." Jer 31,34b står לא זכר parallelt med סלח: "Jeg tilgiver deres skyld, og deres synd vil jeg ikke længere huske." Denne guddommelige glemsel og udslettelse af synden kan også omskrives med metaforer, fx i kong Hizkijas takkebøn, Es 38,17: "Du kastede alle mine synder bag din ryg". Kierkegaard bruger dette skriftsted til at udtrykke tanken om, at den nok så synlige synd, der er tilgivet, ikke ses: "Det er udslettet, det er tilgivet og glemt, eller som Skriften siger om hvad Gud tilgiver, det er skjult bag hans Ryg." Her tydes gudsbilledet helt antropomorft: Når Gud har kastet al menneskets synd bag sin ryg, så kan selv han ikke se synden; for "netop saaledes tilgiver den Kjerlige: ... kjerligt vender han sig til Den, han tilgiver; men naar han vender sig mod ham, kan han jo ikke see, hvad der ligger bag ved hans Ryg." ${ }^{20}$ Endvidere det udtryksfulde verbum רח , der ordret betyder at "være livmoder", men med rette oversættes at "være barmhjertig", "forbarme sig". ${ }^{21}$ Es 55,7 står det parallelt med סלח: barmhjertighed og tilgivelse hører sammen ligesom i vort udgangspunkt, bekendelsen 2 Mos 34,6b-7, nemlig i gudsnavnet, אל רחום וחנון, Barmhjertig og Nådig Gud (34,6b). ${ }^{22}$ Navnet, der tillige forekommer i bekendelsen Neh 9,31 som det hjemvendte folks fortrøstning, er i sig selv en interpretation efter samme mønster som i 2 Mos 3,14, jf. (Aurelius 1988, 105).

Af synonymer for o skal vi endelig nævne pi'el-formen כפר "ב, der primært betyder "sone" eller "skaffe soning" og er hentet fra offerterminologien. Når כפ derimod har betydningen "tilgive", har det intet

20. Søren Kierkegaard, Kjerlighedens Gjerninger. Søren Kierkegaards Skrifter, bind 9, red. Niels Jørgen Cappelørn m.fl. (København: Gad 2004), 293.

21. Kirsten Nielsen bemærker om substantivet רח (raham) "livmoder", at når et så udpræget kvindeligt udtryk hører hjemme i beskrivelsen af Guds faderlige barmhjertighed, passer det fint med, at Guds billede iflg. 1 Mos 1,27 er både mand og kvinde. Jf. Gertrud Yde Iversen \& Kirsten Nielsen, En indforing i Bibelen (København: Bibelselskabets Forlag 2010), 88f.

22. Bemærk spændingen mellem dette nådefulde gudsnavn og det kompromisløse

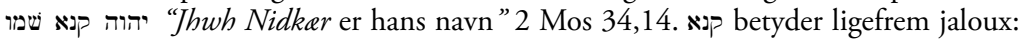
Jhwh tåler ikke andre guder ved sin side. Dette ofte forekommende navn er den stærkest tænkelige betegnelse for den elskende Gud og står således ikke i modsætning til det nådefulde navn i 34,6b, men bekræfter det. Jf. Eduard Nielsen, De Ti Bud. En traditionshistorisk skitse, Festskrift for Hans Majestæt Kongen (København: Københavns Universitet 1965), 83ff. 100. 
med menneskers ofre og præstationer at gøre, men står helt for Guds egen handling. I den føreksilske tekst om profeten Jesajas kaldelse (Es $6,6 f$ ) er soningen af hans synder ganske vist forbundet med en kultisk akt, men forbliver dog helt Guds handling, ledsaget af hans tilsagn: "Din skyld er fjernet, og din synd er sonet." Også Sl 65,4; 78,38a; 79,9b bruges בפר i betydningen "tilgive". Ligesom Es 6,7b er der tale om Gud som den, der af ren barmhjertighed soner menneskenes synder "for (sit) navns skyld", som det understreges dobbelt i Sl 79,9. Soningen er blevet til tilgivelse.

\section{Den tavse tilgivelse}

Foruden de mange sproglige udtryk for tilgivelsen er der også nogle tekster i GT om den tilgivelse, der ikke formuleres i ord. Men netop den uudtalte tilgivelse, som kommer til udtryk i et tegn, fx et kærtegn, eller en generøs, spontan handling, kan under givne omstændigheder være mere betydningsfuld end den ligefrem udtalte tilgivelse.

Den uudtalte tilgivelse som Guds barmhjertige handling over for mennesket, der har forbrudt sig, kender vi fx fra myten om Kain, 1 Mos 4.

Efter drabet på sin bror blev Kain en "flygtning og fredløs" נע ונד (v. 12.14). Det er den nødvendige følge af hans misgerning. Hvordan skulle drabsmanden ellers redde sig? Kun forbandelse kan du høste af "agerjorden, som har spærret sit gab op, for at modtage din brors blod af dine hænder" (v. 11). Derfor måtte Kain flygte fra agerjorden og, som de fleste drabsmænd siden, slå sig ned i landet Nod נור. Navnet betyder "omflakkende liv", "fredløshed" og er sindbilledet på det vilkår, som ikke alene drabet, men enhver misgerning bærer med sig. Som en "fredløs" נד (nadd) måtte Kain bo i Nod. Men hvordan reagerer han på denne skæbne?

"Min straf er for stor at bære", siger han (v. 13). Sådan står der både i DO 1992 og nærmest tilsvarende i DO 1931; og dermed er tanken om den straffende Gud jo nærliggende. Men teksten i BH siger noget andet om Gud. Går vi helt tilbage til oversættelsen fra $1871,{ }^{23}$ så gengives Kains klage: "Min misgerning er større, end jeg kan bære". Begge ord, misgerning og straf, gengiver det hebraiske עון; men iflg. Gesenius forekommer denne glose langt overvejende i betydningen synd, forbrydelse; kun sjældent betegner glosen den straf, gernings-

23. Der henvises her til Det danske Bibelselskabs autoriserede oversættelser af GT 1871 / 1931 / 1992. 
manden må bære som følge af forbrydelsen. I oversættelsen af Kains klage er der ingen grund til at vælge den sjældne betydning af ordet. Pointen er nemlig, at egentlig er det ikke Gud, der straffer; i dybeste betydning ligger straffen implicit i selve forbrydelsen, misgerningen. ${ }^{24}$ Kain kan ikke bære tyngden af sin misgerning. Derfor forbarmer Gud sig over ham. Kain slipper ikke for sin skyldighed; den må han bære med sig i landet Nod. Men netop i dette vildsomme land er han under Guds beskyttelse, som ikke udtrykkes med ordene om blodhævnen (v. 15 a), ${ }^{25}$ men derimod med det tegn, som faktisk sætter hævnen ud af kraft. I stedet for hævnen er det nu barmhjertigheden, der gælder: Gud "satte et mærke på Kain, for at ingen, der mødte ham, skulle slå ham ihjel” (v. 15 b). I konteksten må det forstås som et tegn på Guds tilgivelse, udtrykt i og med, at Kain får et nyt liv i Nod. Han får en familie, bygger en by og grundlægger en stor slægt (v. 17-22).

Således er myten om Kain fortællingen om den uudtalte tilgivelse. Og netop som myte handler den om os alle, som er af Kains slægt og hver på sin vis bor i landet Nod, som skyldige mennesker under Guds tilgivelse.

\section{Undtagelsen fra reglen}

Et andet eksempel på den tilgivelse, der ikke udtrykkes i ord, men i handling, findes i slutningen af den dramatiske fortælling, 2 Sam 13-14. Også den handler om en brodermorder, nemlig Davids søn Absalom, der befalede sine håndgangne mænd at myrde hans bror Amnon, Davids førstefødte søn. Dermed ville Absalom skaffe hævn for sin (hel)søster, Tamar, som var blevet incestuøst voldtaget af Amnon. Efter drabet måtte også Absalom flygte til "Nod", i hans tilfælde det aramæiske Geshur, hvor han opholdt sig i tre år. Kong David, som imidlertid var kommet sig af sorgen over Amnons død, længtes inderligt efter sin søn Absalom, men havde svært ved at forsone sig med ham. Omsider sendte kongen dog bud efter ham; men først efter endnu to år i Jerusalem opnåede Absalom foretræde for sin far,

24. Se Gesenius: נשא עון 2b) נשון 2b 2) samt udtrykket Dette udtryk forekommer hyppigt i den kultiske lovgivning i den specielle betydning "bære sin straf" (3 Mos 5,1; 7,18; 17,16; 19,8;20,20 m.fl.). Dermed er der dog ikke grund til at lægge samme betydning i det tilsvarende udtryk 1 Mos 4,13, som intet med kultisk lov at gøre. Der er således ikke noget i vejen for at fastholde ovennævnte gengivelse i 1 Mos 4,13 af = misgerning. Gesenius (1962), 572. 524.

25. Blodhævnen er ikke eksplicit Guds hævn, men her som i mange oldtidskulturer det krav om gengæld, som det udgydte menneskeblod påkalder sig, "råber" om (v. 10). 
kongen. Hele dette forløb, skildret med sublim fortællekunst, slutter med de få linjer, som i en enkel gestus rummer faderens uforbeholdne tilgivelse: "Kongen lod Absalom kalde. Da han kom, kastede han sig næsegrus til jorden for kongen, og kongen kyssede Absalom" (2 Sam 14,33).

To ting skal bemærkes ved denne fortælling: For det første handler den om den uudtalte tilgivelse; for det andet er det en af de meget få tekster i GT om tilgivelsen mennesker imellem. Ellers er den overalt forbeholdt Gud alene.

Ud over den nævnte undtagelse må vi anføre forsoningen mellem Esau og Jakob (1 Mos 33,1-4). Selve forsoningen eller tilgivelsen er beskrevet med vendinger, som ord til andet er genbrugt i Jesu lignelse om den fortabte søn: Esau "løb ham i møde, omfavnede ham, faldt ham om halsen og kyssede ham", ganske som faderen i lignelsen bar sig ad over for sin fortabte søn (Luk 15,20).

Endvidere kan fortællingen, 1 Mos 50,15-21, med forbehold antyde tilgivelsen mellem mennesker. Her beder Josefs brødre ham om at tilgive dem deres forbrydelse פשע mod ham (jf. 1 Mos 37,23ff). Dog kun indirekte imødekommer Josef dem. Med sit svar "Frygt ikke!" overlader han deres bøn om tilgivelse til Gud, idet han med et forfærdet modspørgsmål afviser den mulighed, at han selv skulle have myndighed til at opfylde den: "Mon jeg er i Guds sted?" Det er Josef ikke, kun Gud kan tilgive.

Blandt de få eksempler i GT på tilgivelsen mellem mennesker skal vi ikke glemme Ordsp 10,12b: "Kærlighed skjuler alle overtrædelser" (citeret 1 Pet 4,8). אהבח kærlighed, nemlig mellem mennesker, ${ }^{26}$ er i dette tilfælde synonym med forsoning, tilgivelse og står som modpol til שנאה had (Ordsp 10,12a). Den tilsvarende modsætning mellem

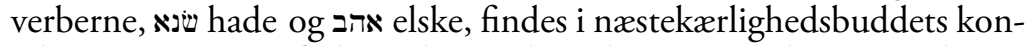
tekst, 3 Mos 19,17f, dog uden at der i den sammenhæng er tale om tilgivelse. Det er tværtimod påfaldende, at næstekærlighedsbuddet i GT aldrig indeholder nogen udtalt opfordring til i givet fald at tilgive næsten, hverken her, hvor buddet formuleres direkte, eller noget af de steder, hvor det forekommer omskrevet (fx 2 Mos 20,12-17; 22,2026; 23,4-9; 3 Mos 19,34; 5 Mos 5,16-21; 10,19; 22,1-4; 2 Kong 6,22; Es 1,17; Mika 6,8; Ordsp 25,21).

Som undtagelse skal vi endnu nævne Jonas' Bog, hvor den menneskelige tilgivelse ikke er til stede, men hvor Gud efterlyser den. Men undtagelserne bekræfter reglen: Kun Gud kan tilgive. Dette var stadigvæk synspunktet i jødedommen på Jesu tid, jf. Mark 2,7; Luk 5,21 .

26. Derimod betegnes Guds kærlighed oftest som [oח [hasad], jf. note 8. 


\section{Guds tilgivelse og menneskets ansvarlighed}

Guds tilgivelse, som den stadfæestes af 2 Mos 34,6b-7 og alle dermed beslægtede tekster, er betingelsesløs og sætter dermed mennesket fri, men underkender på ingen måde dets skyldighed over for medmennesket, næsten.

Fra kong Davids personlige historie (2 Sam 11-12) kendes eksemplet, hvor et menneskes uret er så definitiv, at det kun har ét at gøre. Da profeten Natan, sendt af Gud, kommer til kongen og pointerer sin straffetale med afsløringen: "Du er manden!", har David kun det eneste svar: "Jeg har syndet mod Jhwh" (2 Sam 12,7a.13a). Uretten finder sted i menneskers verden og giver årsag til bitter lidelse dér; men som synd er den rettet mod Gud alene. Den er for tung at bære; ${ }^{27}$ kun Gud kan tilgive den. GT.s fastholdelse af dette indikerer, at menneskets skyld tages alvorligt, jf. Sl 51, som det var så nærliggende for en senere redaktion at relatere til denne begivenhed i Davids liv (v. 1), og hvor digteren bekender for Gud: "Mod dig, mod dig alene har jeg syndet, ..." (v. 6).

Overordnet hænger dette synspunkt sammen med det første buds og dermed monoteismens dominans i gammeltestamentlig lovforståelse, ja, i GT i det hele taget. Det første bud, "Du må ikke have andre guder end mig" (5 Mos 5,7ff, jf. 2 Mos 20,3ff), ${ }^{28}$ må ses i lyset af Israels Credo med det store bud i loven, kærlighedsbuddet 5 Mos 6,4f. Dette forhold formuleres stringent af Crüsemann med udsagnet om "die begrifflich scharfe Erfassung der Einheit und Einzigkeit dieses Gottes im Schema' Jisrael ([Dtn] 6,4ff), mit dem die älteren Fassungen des ersten Gebotes überboten und bis an die Schwelle des Monotheismus radikalisiert werden." ${ }^{29} \mathrm{Al}$ synd i verden mod Gud og mennesker skyldes i grunden tilsidesættelsen af kærligheden til denne eneste Gud. Derfor kan kun Gud tilgive synden, som det sker for David, da Natan forkynder ham Guds nådige dom: "Så tilgiver Jhwh din synd. Du skal ikke dø" (2 Sam 12,13b). Tilgivelsen var ubetinget, og Davids gudsforhold dermed genoprettet.

Men i de medmenneskelige forhold, personlige og private såvel som offentlige og politiske, måtte David som den ansvarlige bøde for sin skyldighed (2 Sam 12,9-12.14). Menneskets synd er gudsrelateret;

27. Jf. Sl 38,5: "Mine synder vokser mig over hovedet, som en tyngende byrde er de for tunge for mig."

28. I begge udgaver af dekalogen (2 Mos 20,3-17; 5 Mos 5,7-21) tegner det første bud sig i teologisk betydning for langt over halvdelen af teksten, dvs. for de første fire bud til og med sabbatsbuddet.

29. Frank Crüsemann Die Tora. Theologie und Sozialgeschichte des alttestamentlichen Gesetzes (Gütersloh, Kaiser 1997), 238. 
men dets ansvar for den relateres til medmennesket og samfundet. Dette er en vigtig grundtanke i GT: Guds ubetingede tilgivelse fritager ikke den skyldige for det medmenneskelige og offentlige ansvar. Dette ansvarsforhold beror især på næstekærlighedsbuddet, som står et helt andet sted i toraen (3 Mos 19,18.34) end det store bud om kærligheden til Gud (5 Mos 6,4f); men begge bud står implicit side om side i dekalogen (jf. 2 Mos 20,3-11.12-17; 5 Mos 5,7-15.16-21). Dermed er det helt relevant at tale om det "dobbelte kærlighedsbud" i GT.

\section{Den nye pagt i Det gamle Testamente}

Guds enehandling i og med tilgivelsen bliver særlig understreget i de to tekster om den nye pagt (2 Mos 34,9b-10a.27; Jer 31,31-34); den første tekst er formentlig afhængig af den anden (Aurelius 1988, 123ff). Denne pagt, i Jer 31,31 kaldet ברית חרשה "en ny pagt" og i 2 Mos 34,10.27 blot ברית "en pagt", beror ikke som Sinajpagten ${ }^{30}$ på israelitternes lydighed mod loven (2 Mos 19,5.8; 24,3) eller på deres omvendelse (Jer 26,3). Den nye pagt hviler derimod alene på, at Gud uden betingelse tilgiver menneskene (israelitterne) deres skyld, og her bruges typisk det for Gud forbeholdte ord, חל "tilgive" (2 Mos 34,9; Jer 31,34b; 33,8; 36,3). Gud tilsidesætter ikke sin tora, som menneskene brød, men han skriver den ind i deres hjerter og giver dem dermed en helt ny og umiddelbar erkendelse af ham (Jer 31,33f). Den nye pagt i GT er i egentligste betydning tilgivelsens pagt (jf. Feldmeier 2011, 319; Aurelius 1988, 123ff). "Der Gott der Güte und Liebe straft nun nicht mehr drei bis vier Generationen und vergibt Tausenden (Ex 34,6f; Dtn 5,9f), sondern er vergibt einzig und allein, weil Tora im Herzen, Gotteserkenntnis und Vergebung untrennbar sind (Jer 31,33f). Der Bund wird auch in Jer 31 zur reinen Verheissung, aber mit der Tora als entscheidendem Inhalt." (Feldmeier 2011, 456). Vel er Jer 31,31ff et eskatologisk udsagn, men det henvender sig til gudsfolket i den aktuelle situation. Den nære forbindelse mellem den nye pagt, Jer 31,31-34, og Moses' forbøn om tilgivelse, 2 Mos 34,9,

30. Gennemgående bruges i den foreliggende tekst betegnelserne Sinajpagten og Sinaj bjerg, selv om det fortrinsvis er fra 2 og 3 Mos, vi kender dette stednavn, medens samme bjerg i 5 Mos (men også 2 Mos 3,1; 17,6; 33,6; 1 Kong 8,9; 19,8; Mal 3,22; Sl 106,19; 2 Krøn 5,10) kaldes Horeb. 
der besvares med Guds pagtstilsagn, 34,10.27, ${ }^{31}$ understreger både, at her hører pagt og tilgivelse sammen, og at begge gives af Gud alene.

\section{Gud bliver anderledes}

Imidlertid kan der med hensyn til tilgivelsens teologi spores en afgørende forskydning i den gammeltestamentlige gudsopfattelse. Over tid har den flyttet sig fra forestillingen om den vrede og straffende Gud til troen på den barmhjertige og nådige Gud. Denne bevægelse i gudsopfattelsen viser sig allerede i vort udgangspunkt, bekendelsen 2 Mos 34,6b-7. Kun tilsyneladende går bevægelsen her i modsat retning: fra barmhjertigheden v. 6b-7a, til straffen v. $7 \mathrm{~b}$; men forholdet bliver præcis det omvendte, når man iagttager den asymmetri mellem nåden og vreden, som bl.a. Konkel, Spieckermann og Dohmen påviser, og som $g ø r$, at ordene om vreden især tjener til at forstærke udsagnet om nåden. Det er denne vending i gudsbegrebet, som er Aurelius' tese i undersøgelsen af perikopen 2 Mos 32-34 (Aurelius 1988, 57-126). Tesen med hovedtemaet "Gott wird anders" (s. 91) belyses i fem tekstforløb med det fælles emne, Guds fortrydelse og hans tilgivelse:

1) Først Am 7,1-9; 8,1-3,32 som i substansen, nemlig domsudsagnene, hører hjemme i den profetiske forkyndelse i 8. årh. f.Kr., hvorimod forbindelsen mellem domsbudskabet og de profetiske forbønner snarere er beslægtet med den langt senere Jeremiasbog (jf. Feldmeier 2011, 317). Amos ser i fire visioner Guds dom over Israel, hvormed der givetvis sigtes til Nordrigets undergang 722 f.Kr. Under den første vision (7,1-3: græshopperne, der æder alt græs i landet) beder profeten indtrængende for det lille folk, som er truet af den assyriske stormagt: "Gud Jhwh, tilgiv dog! ${ }^{33}$ Hvordan skal Jakob bestå, så lille han er?" Men bønnen bliver ikke opfyldt. Gud vil ikke tilgive sit folk. Kun indtil videre lægger han bånd på sin vrede (Aurelius 1988, 122). Andet og mere ligger der ikke i verbet נחם (nif'al) "fortryde", som

31. Det er ganske vist påfaldende, at det afgørende ord i bønnen 2 Mos 34,9, nemlig סלח "tilgive", ikke bliver taget op eller reflekteret i 34,10ff. Måske kan dette forklares med den hypotese, som Aurelius fremsætter, at hele afsnittet 34,10-27 oprindelig har haft en anden placering (efter 33,12-17?), Aurelius (1988), 104-106.

32. Aurelius forholder sig i denne forbindelse kun til Am 7,1-6, Aurelius (1988), 82f. 93.122. Men for nærværende medtages Am 7,7-9; 8,1-3, da disse vers i konteksten hænger nøje sammen med 7,1-6, jf. Feldmeier (2011), $316 \mathrm{f}$.

33. Am 7,2 er den ældste tekst i GT, hvor vi møder det for Guds tilgivelse forbeholdte verbum סלח, her i forstærket imperativ: סלח־נא "tilgiv dog!" 
ikke må forveksles med סלח “tilgive”. ${ }^{34}$ Guds svar på Amos' forbøn under den næste vision (7,4-6: den fortærende ild) ligner meget det første. Ved den tredje vision (7,7-8: om manden på bymuren med et blylod i hånden), der må forstås som et billede på den umiddelbare politiske og militære trussel mod hovedstaden Samaria, er profetens forbøn helt forstummet. Den fjerde vision (8,1-2: kurven med moden frugt) handler om den endelige katastrofe med jamrende sangerinder og dynger af lig overalt $(8,3)$. Gud vil ikke længere "gå forbi" עבר (dvs. skåne) sit folk $(7,8 \mathrm{~b} ; 8,2 \mathrm{~b})$.

2) Der er visse forbindelser mellem denne Amostekst og Moses' to forbønner 2 Mos 32,11-14. 31-34 (Aurelius 1988,82.93). Ligesom hans øvrige forbønner i perikopen 2 Mos 32-34 må også disse to ældste regnes for (efter)eksilske. Deres baggrund er fortællingen om guldkalven, som israelitterne og Aron under Moses' fravær havde fremstillet og dyrket som en gud, der i stedet for Moses skulle gå foran dem $(32,1 \mathrm{ff})$. Frafaldet proklameres med ordene: "Disse er dine guder, Israel, som førte dig op fra Egypten!" $(32,4 \mathrm{~b})$. BH.s pluralis i denne sætning (også i verbet) er sikkert hentet fra 1 Kong 12,28f, hvor Jeroboam I med den samme proklamation hylder de to guldtyrekalve, som han 935 f.Kr. opstillede i Betel og Dan i opposition mod tempelkulten i Jerusalem. Med Am 7,9 ligger den antagelse lige for, at det just er denne oprørende handling, Jeroboams synd, som domsbudskabet i Am 7,1-9; 8,1-3 refererer til. Når 2 Mos 32 fører det samme frafald tilbage til Sinaj-historien, karakteriseres det dermed som folkets ursynd, Israels syndefald. Moses, som håber at formilde Guds tilintetgørende vrede, beder i første omgang ikke om tilgivelse for folket, men kun om, at Gud vil נרעה Jartrydet onde" (ulykken) mod sit folk (32,12b). Gud føjer Moses $(32,14)$; men denne guddommelige fortrydelse, både i Exodus- og Amosteksten udtrykt med verbet נם, er kun en midlertidig udsættelse af dommen, "nicht Sündenvergebung, eher göttliche Selbstbeherrschung, die letztmögliche Weise der Bewahrung Israels vor dem Gericht" (Aurelius 1988, 93). Alligevel vover Moses i den næste bøn at anråbe om tilgivelse for folket, endda med sin egen salighed som indsats $(32,32)$; men Guds svar er ikke desto

34. De markante udsagn om, at Gud "omvender sig" שיב og "fortryder" נחם (nif'al) det onde, hvormed han har planlagt at straffe mennesker, forekommer ofte (jf. 2 Mos 32,12.14; 2 Sam 24,16; Jer 18,8; 26,3.13.19; Joel 2,14; Am 7,3; Jon 3,11; 4,2; Zak 8,14f; Sl 106,45f; 1 Krøn 21,15). Guds fortrydelse er dog ikke nødvendigvis ensbetydende med hans tilgivelse. Således tales der i 2 Mos 32,7-14 ikke om tilgivelse, men om Guds fortrydelse for sit eget omdømmes skyld (v. 12b) og for fædrenes skyld (v. 13). For det meste er der væsentlig forskel på, om Gud "fortryder" נג eller "tilgiver" חל, jf. Aurelius (1988), 94. 
mindre den ufravigelige dom: "Men på dagen for min hjemsøgelse vil jeg hjemsøge deres synd på dem" $(32,34 \mathrm{~b})$, hvormed der sikkert hentydes til Nordrigets fald 722 f.Kr.

3) 2 Mos 32,11-14 - 34,6f - 34,9b. Der er et afgørende skridt fra נחם, Guds fortrydelse i og med hans tilbageholdelse af vreden, 2 Mos 32,11-14, til סל, hans uforbeholdne tilgivelse af sit "stivnakkede" folk, 34,9. Men imellem disse to yderpunkter står tilgivelses-theophanien, hvor Gud עבר "går forbi" Moses, 34,6 (jf. 33,19;35 1 Kong 19,11a) og udråber ordene: "Jhvh, Jhwh er en barmhjertig og nådig Gud... Han bevarer (sin) kærlighed i tusind slægtled, idet han tilgiver..." (34,6b-7a). Moses hører slet ikke fortsættelsen om, at Gud ikke lader den skyldige ustraffet... (34,7b), men holder fortrøstningsfuldt fast ved Guds tilgivelse. I bønnen solidariserer Moses sig helt med det syndige folk: “... for vel er det et stivnakket folk; men du tilgiver vor skyld og vor synd og du gør os til arv" $(34,9 b)$. Dette er ikke en imperativisk forbøn, som Aurelius i sin oversættelse gør den til: "... denn es ist ein halsstarriges Volk, aber vergib unsere Schuld und Sünde, und 'erbe' uns" (Aurelius 1988, 122). Aurelius svækker sin egen pointe i samme forbindelse, "dass Gott jetzt anders geworden ist", ved ikke at iagttage det, der afgørende adskiller denne bøn fra Moses' andre forbønner i 2 Mos 32-34, som alle i BH er insisterende anråbelser, udtrykt i imperativ $(32,12 \mathrm{~b})$, eller jussiv (32,32a), og igen imperativ $(33,13 \cdot 18)$. I bønnen $34,9 b$ står verberne hverken $\mathrm{i}$ imperativ eller jussiv, men derimod i konsekutiv perfektum, der bedst oversættes som en konstaterende præsens: "... thi et stivnakket folk er det; men "du tilgiver" וסלחת os ... og "du gør os til arv" ונחלתנו." Moses anråber ikke om, at folket og han med det må få tilgivelse og arvelod, men han fortrøster sig til, at den bøn allerede er hørt med Guds nådige tilsagn 34,6b-7a. Israel har ikke ændret sig; men Gud er blevet anderledes, det er pointen; og det er just, hvad Moses i denne bøn erkender. Det samme stivnakkede folk, som Gud iflg. 32,9f ville tilintetgøre, det tilgiver han iflg. 34,9 og gør det til sin arvelod. Nåden (34,6-7a) er kommet imellem.

4) I tekstforløbet Jer 26,3 - 31,31-34 - 36,3 ser vi den samme bevægelse fra נחלח "fortryde" tilgive".

Baggrunden for Jer 26,3 er profetien om babylonerkongens erobring af Sydriget (Jer 25) og om templets samt hele Jerusalems undergang (Jer 26, jf. Jer 7). De to udsagn, 26,3 og 36,3, begge anført som

35. 2 Mos 33,19f er en senere, men kontekstuel saglig udlægning af 34,6, jf. Aurelius (1988), 125. 
Guds ord, er nærmest identiske; kun i slutningen er de afgjort forskellige: "Måske vil de høre og vende om, enhver fra sin onde vej, så vil jeg fortryde ונחמתי det onde, som jeg tænker på at gøre mod dem..." $(26,3)$. "Måske vil judæerne høre om alt det onde, som jeg tænker på at gøre mod dem, så at de vil vende om, enhver fra sin onde vej, så vil jeg tilgive יוסלחת deres skyld og deres synd" $(36,3)$.

Men midt imellem disse to udsagn står forjættelsen om den nye pagt, Jer 31,31-34. Den adskiller sig udtrykkeligt fra Sinajpagten, som israelitterne brød, og betyder, at Guds hellige tora nu ikke længere spærrer mellem ham og det ulydige folk; for han lægger den i deres indre og skriver den i deres hjerter. Forjættelsen slutter med det tilsagn, som er pagtens fundament: "Thi jeg tilgiver deres skyld og husker ikke længere på deres synd." Den nye pagt er tilgivelsens pagt og dermed forudsætningen for det afgørende skridt fra נחסח (26,3) til (36,3).

Sandsynligvis har netop disse Jeremiastekster dannet forlæg for den tilsvarende overgang, som vi bemærkede i Exodusteksterne, fra 2 Mos 32,14 (Guds tilbageholdte vrede) via 34,6-7a (nådeformlen) til 34,9b (Guds uforbeholdne tilgivelse). Aurelius bemærker den interessante omstændighed, at det ofte forekommende verbum o "tilgive" kun to steder i GT, nemlig 2 Mos 34,9 og Jer 36,3, har de to objekter עלון og חטאת ("skyld" og "synd"), tilmed i samme rækkefølge (Aurelius 1988, 123). Ligeså må det antages, at det er den nye pagt i Jer 31,3134 , som der kort refereres til i 2 Mos 34,10.27. I Jeremiasbogen lyder forjættelsen om den nye pagt til de jøder, som overlevede templets og Jerusalems ødelæggelse 587 f.Kr. I samme historiske kontekst må vi forstå pagten i 2 Mos 34, hvor den blot tydes med den mytiske Sinajfortælling.

5) Endnu en tekst er sandsynligvis formet under indflydelse af Jer 26,3 - 31,31-34-36,3, nemlig refleksionerne over syndflodsmyten, 1 Mos 6,5-7 - 8,1-2 -8,21. Dette tekstforløb danner en tydelig parallel til de ovennævnte forløb i Jeremiasbogen og i 2 Mos 32-34. ${ }^{36}$ 1 Mos 6,5-7 hedder det: "Da Jhwh så, at menneskenes ondskab på jorden var stor, og alle planer, som de udtænkte i deres hjerte, kun var ondskab dagen lang, så fortrød וינחם Jhwh, at han havde skabt menneskene på jorden.” Fortrydelsen medførte hans beslutning om at udslette menneskene og hele sit øvrige skaberværk. Men 8,21 træffer Gud den stik modsatte beslutning om aldrig mere at forbande jorden på grund af menneskene. Ikke-forbandelse er ensbetydende med tilgivelse; men nu er begrundelsen den selvsamme nøgterne indsigt

36. 1 Mos 6-8 er en "vorpriesterschriftlich" overlevering og næppe ældre end 2 Mos 32-34, jf. Aurelius (1988), $124 \mathrm{f}$. 
som før: "thi כ menneskets hjertes higen er ond fra ungdommen af." Forklaringen på to så modsatrettede beslutninger med samme begrundelse ligger igen(!) i det, som står imellem dem, in casu Guds nye skabelse ${ }^{37}$ efter syndfloden $(8,1 \mathrm{ff})$. Med den nye skabelse følger Guds pagt med Noa og hans efterkommere med tilsagnet: "Aldrig mere skal alt levende udslettes af vandfloden..." (9,9-11). Således er Noa-pagten tilgivelsens pagt ganske som den nye pagt i Jer 31. Med citat af $\mathrm{L}$. Perlitt fastslår Aurelius "Die Flut hat offenbar nicht den Menschen verwandelt, sondern Gott!" og konkluderer: "Und das ist auch das Fazit von Ex 32-34: Nicht das Volk ist anders geworden, sondern Gott" (Aurelius 1988, 125).

Samme pointe, som Aurelius udleder af de tre tekstfortløb Jer 26,3 - 31,31-34 - 36,3; 2 Mos 32,11-14 - 34,6f - 34,9 og 1 Mos 6,5-7 - 8,1-2 - 8,21 (i den rækkefølge!) kan findes i Jonas' Bog. Gud taler ikke mere om "hjemsøgelse" eller straf, men tilgiver, forjætter og forpligter synderne på ny. Gud er blevet anderledes, men er jo ikke dermed blevet en anden Gud. Tværtimod er det i overensstemmelse med hans inderste væsen, når han handler som "en barmhjertig og nådig Gud", der "tilgiver skyld, overtrædelse og synd" (2 Mos 34,6) (jf. Aurelius 1988, 116).

I begyndelsen af denne afhandling blev det fastslået, at GT i første række handler om nåden og den nådige Gud. Hvordan skal vi heroverfor forstå Aurelius' udtryk "Gott wird anders"? Det er vigtigt at bemærke, i hvilken kontekst det bruges. Når man som Aurelius taler om den straffende Gud, der ved nådens mellemkomst bliver den tilgivende Gud, har man jo netop præciseret nåden som Guds primære anliggende. Det er det samme, som siges med nådeformlen (2 Mos 34,6b-7).

Den todimensionale tilgivelse - eller Jonas og den femte bøn

I Jonas' Bog får tilgivelsen antydning af en dimension, som ellers ikke forekommer i GT. I relation til vort emne kan essensen af dette særprægede lille skrift samles i få linjer:

To gange fik Jonas befaling om at udråbe Guds vrede og dom over den syndige, hedenske storby Ninive (Jon 1,1f; 3,1f). Første gang trodsede Jonas Guds befaling $(1,3)$, men fulgte den anden gang $(3,3)$. Men mod Jonas' forventning troede ninivitterne Gud på hans ord og gjorde omgående bod. Deres konge befalede generalfaste og bod,

37. Bemærk den sproglige forbindelse mellem 1 Mos 8,1f og 1 Mos 1,2. 
så alle folk i byen tillige med samtlige køer og får, skulle klæde sig i sæk (3,5-9). ${ }^{38}$ Da Gud så, at de omvendte sig, fortrød han ulykken og forbarmede sig $(3,10) .{ }^{39}$ Guds holdningsændring frustrerer i den grad Jonas, at han forbitret anfører den og dermed selve nådeformlen (2 Mos 34,6b) som begrundelse for sin egen ulydighed, Jon 4,1-2.

I en jødisk kontekst markerer Jonas' Bog sig med en provokerende skarphed ved, at hedningerne omvender sig og gør bod over for Israels Gud, og at det fremfor alt er dem, han forbarmer sig over og tilgiver. ${ }^{40}$ Dog forbarmer Gud sig også over den ulydige jøde Jonas ved at redde ham i havsnød $(2,1.11)$, tilgive og oprejse ham $(2,3.7),{ }^{41}$ tage ham $\mathrm{i}$ sin tjeneste påny $(3,1 \mathrm{f})$ og befri ham fra mismod $(4,6)$. Men hvordan forholder den tilgivne Jonas sig til alle de hedenske skyldnere i Ninive og navnlig til Guds barmhjertighed mod dem? To gange $(4,4.9 \mathrm{a})$ spørger Gud: "Har du ret til at være vred?" $42 \mathrm{Og}$ Jonas svarer med at hævde sin ret til at være "vred til døden" $(4,3.9 \mathrm{~b})$ og fremturer således i sin harme over, at hedningerne ikke får løn som forskyldt. Men over for Jonas' angivelige ret til vrede står Guds barmhjertighed: "Skulle jeg så ikke have ondt af den store by...?" $(4,11)$. Dermed efterlyser Gud den samme barmhjertige og tilgivende holdning hos Jonas, og således er Jonas' Bog vel den tekst i GT, der tydeligst sigter på den menneskelige tilgivelse.

38. Om livsfællesskabet mellem mennesker og dyr i Jonas' Bog, se Kirsten Nielsen, Gud, Mennesker og Dyr i Bibelen (København: Anis 2013), 46f.

39. Ordene om, at Gud måske vil fortryde (נחם), og vende om fra sin glødende vrede, er her lagt i munden på den hedenske konge $(3,9)$, men er nøje kopieret efter Moses' forbøn (2 Mos 32,12b), og i begge tilfælde følges forbønnen / kongens ord op af Guds fortrydelse af den ulykke, som han havde besluttet mod hhv. israelitterne i ørkenen $(2$ Mos 32,14) og den hedenske befolkning i Ninive (Jon 3,10). Parallelismen mellem de to tekster er gennemført; for i dem begge fører forbønnen / de kongelige ord og Guds fortrydelse i sidste ende frem til nådeformlen, 2 Mos 34,6b; Jon 4,2c. Til forskel fra Am 7,3.6; 2 Mos 32-34; Jer 26,3.13.19 er Guds fortrydelse i Jonas' Bog $(3,9-10 ; 4,2)$ dog ensbetydende med hans tilgivelse. Selve glosen o "tilgive" forekommer ikke i dette skrift. Jf. note 34 .

40. Bemærk den samme vigtige pointe i Jesu forkyndelse med reference til Jonas' Bog, Matt 12,41; Luk 11,32.

41. Ældre forskning har betragtet salmen, Jon 2,3-10, som en sekundær interpolation, fordi dens sprog er helt anderledes end den øvrige fortælling, jf. fx Gabriel H. Cohn, Das Buch Jona im Lichte der biblischen Erzählkunst (Amsterdam: van Goreum 1969), 25. Modsat hævder Kirsten Nielsen: "Men argumentet holder ikke. Hvis Jonas skal synge en salme, må den være genkendelig som salme og derfor holdt i salmesprog", Kirsten Nielsen, Det Gamle Testamente på gudstjenestens betingelser (København: Anis 2003), 284.

42. Anden gang (Jon 4,9) er spørgsmålet ganske vist relateret til Jonas' vrede over at have mistet den skyggefulde olieplante, men det er dog i grunden den samme vrede, som den, der spørges til i 4,4. 
Spørger vi om skriftets affattelsestid, indikerer forskellige hentydninger til eller i andre skrifter (fx 1 Mos 19,29; 2 Mos 14,12; 16,2f; 32,12b.14; 34,6f; 1 Kong 19,1-19; 2 Kong 14,25; Jer 18,7-11; 26,3.13.19; Joel 2,13f), at disse har foreligget, da Jonas' Bog blev forfattet. Den er således sandsynligvis blevet til inden for de seneste førkristne århundreder, dog senest 2. årh. f.Kr., eftersom den er kendt af Sirak $(49,10) .{ }^{43}$

Der er i det mindste to betydningsfulde forbindelser mellem Jonas' Bog og de synoptiske evangelier i NT. Den ene forbindelse knytter Jesus i forkyndelsen af Guds barmhjertighed mod hedningerne fremfor hans egne forstokkede landsmænd, jf. ordene om Jonastegnet (Matt 12,39-41; Luk 11,29-32). Den anden består i, at man næppe kan undgå at blive mindet om den femte bøn i Fadervor, når man læser Jonas' Bog.

Jonas bliver selv genstand for Guds barmhjertighed, men fortørnes over, at Gud tilgiver hedningerne. Overfor denne nådeløse holdning hos Jonas står Guds spørgsmål som fortællingens slutreplik: "Skulle jeg så ikke forbarme mig over den store by Ninive...?” (Jon 4,11).

Jesus vægter i den grad tilgivelsen mellem mennesker, at han gør den til forudsætning for Guds tilgivelse. Derfor hedder det: "Forlad os vor skyld, som vi også har forladt ${ }^{44}$ vore skyldnere" (Matt 6,12). Samme forudsætning ligger i de Jesus-ord, som Mattæus føjer umiddelbart til Fadervor (Matt 6,14f). Således kan Matt 6,12.14f læses som kontekst til Jonas' Bog, hvor Gud efterlyser den menneskelige tilgivelse.

Den betydningsfulde plads, som Jonas-skikkelsen eller Jonas' tegn har i Jesu forkyndelse, må sammenholdes med flere andre fællestræk mellem Jonas' Bog og karakteristiske evangeliske udsagn om nåden, fx Matt 18,33-35; 20,15-16; Luk 6,36. Mht. tilgivelsens teologi i GT er pointen i Jonasbogen enestående; men hermed befinder vi os jo også på tærsklen til nytestamentlig tid.

\section{Skillelinjen mellem de to testamenter}

Spørgsmålet, hvorfor GT taler så ensidigt om tilgivelsen, blev i foranstående givet med henvisningen til det første bud og buddet om kærlighed til Gud (5 Mos 5,7ff; 6,5): Da al synd mod Gud og mennesker har rod i overtrædelsen af det første bud og dermed i fornægtelsen af kærligheden til den eneste Gud, kan kun han tilgive synden.

43. Jf. Karin Friis Plum “Jonas, Jonas' Bog”, Gads Bibelleksikon I, (København: Gad 1998), 386f.

44. Således efter den bedst bevidnede græske læsemåde: perfektum $\alpha \varphi \eta ́ \kappa \alpha \mu \varepsilon v$. 
Svaret på det næste spørgsmål, nemlig om den beskedne plads, tilgivelsen mellem mennesker har i GT, kunne for så vidt være, at der i GT insisteres så vedholdende og ufravigeligt på Guds eneprioritet $\mathrm{i}$ tilgivelsen, så der simpelthen ikke er blevet plads til den menneskelige tilgivelse i de kanoniserede gammeltestamentlige skrifter. Men den virkelige årsag til, at denne dimension er så fraværende, er snarere, at den har savnet en egentlig teologisk begrundelse. Dette udelukker ingenlunde, at tilgivelsen har været til stede i det levede liv og fællesskab mellem mennesker i Israel. Det har den ganske sikkert, ligesom $i$ alle andre folk på jorden. Der er ingen grund til at antage andet.

Den teologiske begrundelse for tilgivelsen på det menneskelige plan ligger imidlertid et andet sted, nemlig i inkarnationen, dvs. Guds menneskevordelse i Jesus Kristus, omfattende hele hans menneskeliv fra undfangelse og fødsel til kors og død. Inkarnationen danner skillelinjen mellem GT og NT, hvilket markeres særlig tydeligt i opfattelsen af tilgivelsen. Israels Gud er den samme Gud, som den kristne menighed bekender sig til; men GT har ikke noget budskab om, at denne ene og samme Gud blev menneske, hvormed også hans tilgivelse blev menneskeliggjort. I Jesus er den blevet kød og blod (jf. Rom 8,1-3), blevet menneske-lig, og skal dermed i Jesu navn gives videre: "Tilgiv hinanden, ligesom også Gud i Kristus har tilgivet jer" (Ef 4,32b). Denne todimensionale tilgivelse er det nye i forhold til GT.s ensidige opfattelse af tilgivelsen. ${ }^{45}$

\section{Sammenfatning}

Som et bibelteologisk projekt på kanonisk grundlag har denne studie knyttet til ved forskere som Childs og Spieckermann i sin undersøgelse af tilgivelsen i GT i dens oftest forekommende konception, nemlig den ikke-kultiske. Denne er behandlet med udgangspunkt $i$ en central gammeltestamentlig tekst, den bekendelseslignende nådeformel, 2 Mos 34,6b-7, hvis udsagn fungerer som pejlemærke gennem hele det foreliggende arbejde. Guds evige tilgivelse, som dette credo pointerer, må ses på baggrund af hans straffende vrede over menneskenes frafald og synd; men i dets udformning er det særlig vigtigt at iagttage vægtningen mellem nåden og straffen, til nådens fordel (jf. Spieckermann og Konkel). Denne vægtning er ikke på for-

45. I NT er det ikke muligt at isolere inkarnationen fra opstandelsesevangeliet, idet alle beretninger om Jesu liv og forkyndelse er gennemlyst af evangeliet om ham som den opstandne og levende Kristus. Ikke desto mindre er det i tilgivelsens teologi netop inkarnationen, der markerer skillelinjen mellem GT og NT. 
hånd indlysende, idet der, som vist af Aurelius, finder en forskydning sted over tid fra vreden til nåden. Guds tilgivelse er ubetinget, men forpligter samtidig mennesket i ansvaret over for dets næste, jf. det dobbelte kærlighedsbud i GT. De få eksempler i GT, hvor der er tale om menneskers tilgivelse, må betragtes som de undtagelser, der bekræfter hovedtesen om Guds eneprioritet på tilgivelsen.

Når tilgivelsen på det menneskelige plan forekommer så sjældent $\mathrm{i}$ GT, må det især skyldes, at den savner teologisk begrundelse i GT i og med, at det ikke kender inkarnationen. Først med den, dvs. først med NT, bliver tilgivelsen todimensional. I NT er der en nødvendig sammenhæng mellem Guds tilgivelse af menneskets skyld og menneskets vilje til at tilgive sin næste. I konceptionen af tilgivelsen er det således inkarnationen, der danner skillelinjen mellem de to testamenter. 